\title{
Enterotoxin Production by Bacillus cereus Under Gastrointestinal Conditions and Their Immunological Detection by Commercially Available Kits
}

\author{
Siele Ceuppens, ${ }^{1,2}$ Andreja Rajkovic, ${ }^{1,3}$ Stefanie Hamelink,, ${ }^{1,2}$ Tom Van de Wiele, ${ }^{2}$ \\ Nico Boon, ${ }^{2}$ and Mieke Uyttendaele ${ }^{1}$
}

\begin{abstract}
Currently, three commercial kits for Bacillus cereus enterotoxins Nhe and/or Hbl detection are available, namely, the Bacillus diarrheal enterotoxin visual immunoassay (BDE VIA $\left.{ }^{\mathrm{TM}}\right)$ kit (3M Tecra), B. cereus enterotoxin reversed passive latex agglutination (BCET-RPLA) kit (Oxoid), and the Duopath ${ }^{\circledR}$ Cereus Enterotoxins (Merck). The performance of the kits and their applicability to gastrointestinal simulation samples were evaluated. Then, the stability and production of enterotoxins $\mathrm{Hbl}$ and $\mathrm{Nhe}$ under gastrointestinal conditions were investigated. Enterotoxin production was absent or impaired at acidic $\mathrm{pH}$, i.e., in gastric medium with $\mathrm{pH} 5.0$ and lasagne verde with $\mathrm{pH}$ 5.5. B. cereus did produce enterotoxins Nhe and $\mathrm{Hbl}$ during anaerobic growth in intestinal medium at $\mathrm{pH} 7.0$, but the toxins were instantly degraded by the enzymes in the host's digestive secretions. Preformed enterotoxins did not withstand gastrointestinal passage under the simulated conditions, which suggests that preformed enterotoxins in food do not contribute to the diarrheal food poisoning syndrome. In conclusion, diarrhea is probably caused by de novo enterotoxin production by B. cereus cells located closely to the host's intestinal epithelium.
\end{abstract}

\section{Introduction}

B ACILLUS CEREUS CAN CAUSE EMETIC and diarrheal food poisoning by production of cereulide and several enterotoxins such as non-hemolytic enterotoxin (Nhe), hemolysin BL ( $\mathrm{Hbl}$, cytotoxin K (CytK) and enterotoxin FM and virulence factors such as hemolysins (HlyII and HlyIII), collagenases, phospholipases $\mathrm{C}$ and cereolysins, respectively (Ceuppens et al., 2011).

B. cereus enterotoxins are unstable molecules, susceptible to heating $\left(>55^{\circ} \mathrm{C}\right.$ for $\geq 20 \mathrm{~min}$ ) and protease activity (pronase, pepsin, trypsin, and chemotrypsin, 1-2 mg/mL, 1-24h) (Granum et al., 1993; Turnbull et al., 1979). As a result, preformed enterotoxins in food are highly unlikely to retain their activity after food preparation and gastrointestinal passage. In contrast, the emetic toxin cereulide is highly resistant to heat (resistant to all normal food processing and food preparation temperatures), acid (resistant to $\mathrm{pH}$ values of 2-11), and protease activity (pepsin and trypsin) (Rajkovic et al., 2008; Shinagawa et al., 1996). Consequently, cereulide is not inactivated during gastrointestinal passage, and preformed cereulide in food plays an prominent role in emetic food poisoning.
Multiple detection methods for enterotoxins exist, including mass-spectrometry, immunological assays, and biological assays such as the vascular permeability reaction, rabbit ileal loop, and cytotoxicity assays. The biological assays are functional assays that determine the overall toxicity, resulting in the advantage of detecting all biologically active toxins with usually high sensitivity. On the other hand, the inherent pitfalls of biological assays are the dubious specificity, resulting in false-positive results for samples which contain other toxins. Moreover, enterotoxins $\mathrm{Nhe}, \mathrm{Hbl}$, and $\mathrm{CytK}$ are all toxic for Vero cells (Wehrle et al., 2009), so a positive cytotoxicity assay requires further analysis to reveal which specific enterotoxins the $B$. cereus strain produces. Similar to the liquid chromatography mass spectrometry (LC-MS) assay for B. cereus emetic toxin cereulide (Delbrassinne et al., 2011), all B. cereus enterotoxins can be detected by mass spectrometry assays (Gilois et al., 2007). The strong points of these methods include their high specificity and sensitivity, while the main drawbacks are the extensive, labor-intensive sample preparation and high investment, running, and maintenance costs. The relatively fast, easy, and cheap immunological detection of enterotoxins make it suitable for research and routine

\footnotetext{
${ }^{1}$ Faculty of Bioscience Engineering, Laboratory of Food Microbiology and Food Preservation (LFMFP), and ${ }^{2}$ Faculty of Bioscience Engineering, Laboratory of Microbial Ecology and Technology (LabMET), Ghent University, Ghent, Belgium.

${ }^{3}$ Department of Food Safety and Food Quality Management, Faculty of Agriculture, Belgrade University, Zemun-Belgrade, Serbia.
} 
Table 1. Overview of the Currently Available Commercial Kits for Bacillus cereus Diarrheal Toxin Detection

\begin{tabular}{|c|c|c|c|}
\hline Characteristics of the kits & BDE VIA ${ }^{\mathrm{TM}}(3 M-$ Tecra $)$ & BCET-RPLA (Oxoid) & Duopath $^{\circledR}$ (Merck) \\
\hline Target toxin component & Nhe-AB & Hbl-L2 & Nhe-B and Hbl-L2 \\
\hline Minimal sample volume $(\mu \mathrm{L})$ & 200 & 50 & 150 \\
\hline Sample type & food & food, isolate & food, isolate \\
\hline \multicolumn{4}{|l|}{ Detection limit (ng/mL) } \\
\hline according to the manufacturer & 1 & 2 & NA \\
\hline according to scientific reports & 2 to $5^{\mathrm{a}}$ & $\geq 0.6^{\mathrm{a}}$ & $6^{\mathrm{b}}$ and $20^{\mathrm{b}}$ \\
\hline Price (€/sample) & 12 & 19 & 14 \\
\hline Time until result $(\mathrm{h})$ & 5 & 20 & 0.5 \\
\hline
\end{tabular}

aBeecher and Wong, 1994.

${ }^{\mathrm{b}}$ Krause et al., 2010.

NA, none available.

analysis. Their sensitivity and specificity for a particular toxin are high, and depend on the antibody quality (Beecher and Wong, 1994). Commercial detection methods for B. cereus enterotoxins are available in the form of immunological kits for components Nhe-A, Nhe-B, and Hbl-L2, but currently none exist for $\mathrm{CytK}$ or other virulence factors. An overview of the presently available kits, namely the BCET-RPLA kit (Oxoid, Lenexa, KS), the BDE VIA ${ }^{\mathrm{TM}}$ kit (3M-Tecra, St. Paul, MN), and the Duopath ${ }^{\circledR}$ kit (Merck, Whitehouse Station, NJ), is presented in Table 1.

The aim of this study was threefold: (i) to compare the currently available commercial kits for B. cereus enterotoxin detection in pure cultures and in gastrointestinal samples; (ii) use these kits to evaluate the enterotoxin stability under gastrointestinal conditions; and (iii) to investigate enterotoxin production by $B$. cereus under gastrointestinal conditions.

\section{Materials and Methods}

\section{Enterotoxin detection}

Samples of approximately $2 \mathrm{~mL}$ were taken. After $\mathrm{pH}$ adjustment of 7.0-8.0 (required by the BDE-VIA ${ }^{\mathrm{TM}}$ kit), the samples were sterilized by filtration over a $0.2-\mu \mathrm{m}$ cellulose acetate membrane filter (Whatman, Springfield Mill, UK; required by the BCET-RPLA kit) and analyzed with the three different kits according to the manufacturer's instructions. The characteris- tics of the three commercial kits presently available for B. cereus enterotoxin detection are presented in Table 1.

\section{Performance of the commercial kits for $\mathrm{B}$. cereus enterotoxin detection}

Antibody cross-reactivity to the medium components and other B. cereus enterotoxins was assessed for all kits by analyzing non-inoculated Tryptone Soya Broth (TSB), BrainHeart Infusion (BHI), and gastrointestinal simulation media, of which the composition was based on an in vitro digestion model (Oomen et al., 2003) with the addition of $8 \mathrm{~g} / \mathrm{L}$ reactor feed for Simulator of the Human Intestinal Microbial Ecosystem (SHIME) (Molly et al., 1993; Possemiers et al., 2004) as the food source. The enterotoxin production of seven B. cereus strains (Table 2) was assessed after cultivation in BHI for $18 \mathrm{~h}$ at $36^{\circ} \mathrm{C}$ (according to the instruction of the BCET-RPLA kit) and in TSB for $24 \mathrm{~h}$ at $30^{\circ} \mathrm{C}$ (in-house protocol). The relative detection limits of the immunological kits were determined by serial dilution of the cell-free culture supernatant of B. cereus American Type Culture Collection (ATCC) 14579 (cultivation in TSB at $30^{\circ} \mathrm{C}$ for $24 \mathrm{~h}$ ) in sterile TSB.

\section{Stability of enterotoxins in TSB, gastric simulation medium, and intestinal simulation medium}

A non-purified mixture of enterotoxins was obtained by filter sterilization $(0.2 \mu \mathrm{m}$ cellulose acetate membrane filter;

Table 2. Enterotoxin Production by Bacillus cereus Strains Cultivated in Tryptone Soya Broth (TSB) FOR $24 \mathrm{H}$ AT $30^{\circ} \mathrm{C}$ AND IN BRAIN-HEART INFUSION (BHI) FOR $18 \mathrm{H} \mathrm{AT} 36^{\circ} \mathrm{C}$

\begin{tabular}{|c|c|c|c|c|c|c|}
\hline \multirow[b]{2}{*}{ B. cereus strain } & \multirow[b]{2}{*}{ Origin } & \multirow[b]{2}{*}{$\begin{array}{l}\text { Minimal growth } \\
\text { temperature }\left({ }^{\circ} \mathrm{C}\right)\end{array}$} & \multicolumn{2}{|c|}{$\begin{array}{c}\text { Haemolysin } \\
\text { BL (Hbl) }\end{array}$} & \multicolumn{2}{|c|}{$\begin{array}{l}\text { Non-haemolytic } \\
\text { enterotoxin (Nhe) }\end{array}$} \\
\hline & & & $\begin{array}{l}\text { BCET-RPLA } \\
\text { (Oxoid) }\end{array}$ & $\begin{array}{l}\text { Duopath }^{\circledR} \\
(\text { Merck) }\end{array}$ & $\begin{array}{l}\text { Duopath }^{\circledR} \\
\text { (Merck) }\end{array}$ & $\begin{array}{c}B D E V I A^{\mathrm{TM}} \\
(3 M-\text { Tecra })\end{array}$ \\
\hline ATCC 14579 & reference type strain & $>10$ & + & + & + & + \\
\hline NVH $1230-88$ & clinical (human faeces) & 8 & + & + & + & + \\
\hline RIVM 9903295-4 & clinical (human faeces) & 7 & \pm & - & + & + \\
\hline FF 137 & food (lasgane verde) & 7 & + & - & + & + \\
\hline FF 73 & food (lasgane verde) & 10 & + & + & + & + \\
\hline LFMFP 381 & food (dried potato flakes) & $>10$ & + & - & + & \pm \\
\hline LFMFP 710 & food (mashed potatoes) & 7 & \pm & \pm & + & \pm \\
\hline
\end{tabular}

ATCC, American Type Culture Collection; NVH, Norwegian School of Veterinary Science (Norwegian: Norges Veterinærhøgskole); RIVM, National Institute for Public Health and the Environment (Dutch: Rijksinstituut voor Volksgezondheid en Milieu); FF, Flanders' Food, Belgium; LFMFP, Laboratory of Food Microbiology and Food Preservation, Ghent University, Belgium.

+ , always positive; -, always negative; \pm , both + and - results obtained; ND, not determined. 
Table 3. Relative Detection Limits of the Immunological Kits, Determined by Dilution of Cell-Free Culture Supernatant of Bacillus cereus American Type Culture Collection (ATCC) 14579 Cultivated in Tryptone Soya Broth (TSB) for $24 \mathrm{H}$ at $30^{\circ} \mathrm{C}$ in Sterile TSB, and the Investigation of Cross-Reactions by Testing the Positive Controls of the Kits and Gastrointestinal Simulation Media and Lasagne Verde as Negative Controls

\begin{tabular}{|c|c|c|c|c|}
\hline \multirow[b]{2}{*}{ Sample } & \multicolumn{2}{|c|}{ Haemolysin BL ( $\mathrm{Hbl})$} & \multicolumn{2}{|c|}{ Non-haemolytic enterotoxin (Nhe) } \\
\hline & $\begin{array}{l}\text { BCET-RPLA } \\
\text { (Oxoid) }\end{array}$ & $\begin{array}{c}\text { Duopath }^{\circledR} \\
\text { (Merck) }\end{array}$ & $\begin{array}{c}\text { Duopath }^{\circledR} \\
\text { (Merck) }\end{array}$ & $\begin{array}{c}\text { BDE VIA } \\
(3 M-\text { Tecra })\end{array}$ \\
\hline \multicolumn{5}{|c|}{ Cell-free culture supernatant of B. cereus ATCC 14579} \\
\hline Undiluted & + & + & + & + \\
\hline $10 \times$ diluted & + & + & + & + \\
\hline $50 \times$ diluted & + & - & + & - \\
\hline $100 \times$ diluted & + & - & + & - \\
\hline $500 \times$ diluted & - & - & - & - \\
\hline Positive control BDE VIA ${ }^{\mathrm{TM}}$ kit (3M-Tecra) & - & - & + & + \\
\hline Positive control BCET-RPLA kit (Oxoid) & + & + & - & - \\
\hline Tryptone Soya broth (TSB) & - & - & - & - \\
\hline Brain Heart Infusion (BHI) & - & - & - & - \\
\hline Gastric medium (undiluted) & + & - & - & - \\
\hline Gastric medium $(2 \times$ diluted $)$ & + & - & - & - \\
\hline Gastric medium $(5 \times$ diluted $)$ & - & - & - & - \\
\hline Intestinal medium (undiluted) & + & - & - & - \\
\hline Intestinal medium $(2 \times$ diluted $)$ & - & - & - & - \\
\hline Intestinal medium $(5 \times$ diluted $)$ & - & - & - & - \\
\hline Lasagne verde $(10 \times$ diluted $)$ & - & - & - & - \\
\hline
\end{tabular}

Whatman) of B. cereus NVH (Norwegian School of Veterinary Science; Norwegian: Norges Veterinærhøgskole) 1230-88 cultivated in TSB for $24 \mathrm{~h}$ at $30^{\circ} \mathrm{C}$. One-milliliter samples of this enterotoxin mixture were incubated statically at $37^{\circ} \mathrm{C}$ in glass tubes containing $9 \mathrm{~mL}$ of sterile TSB with $\mathrm{pH} 7.2$ for $24 \mathrm{~h}$, in gastric simulation medium with $\mathrm{pH} 5.0$ or $\mathrm{pH} 2.0$ for $2 \mathrm{~h}$, and in intestinal simulation medium with $\mathrm{pH} 6.5$ for $2 \mathrm{~h}$.

\section{Enterotoxin production by B. cereus during growth in gastric simulation medium, intestinal simulation medium, and lasagne verde}

B. cereus NVH $1230-88$ vegetative cells $(1 \mathrm{~mL}$ of a $24-\mathrm{h}$ TSB culture at $30^{\circ} \mathrm{C}$ ) were cultured in $59 \mathrm{~mL}$ gastric or intestinal medium for $6 \mathrm{~h}$ with or without competing bacteria in $120-\mathrm{mL}$ glass bottles sealed with rubber caps at $37^{\circ} \mathrm{C}$ with gentle shaking (Yellow Line OS10 shaker [IKA] at 90 rpm) (Ceuppens et al., 2010). The intestinal bacteria were obtained from the colon ascendens vessel of SHIME, in which a mixed bacterial community representative for the human colon is cultivated (Molly et al., 1993; Possemiers et al., 2004). The conditions were indicated as micro-aerobic if the headspace of bottles consisted of air, since the bottles contained 1-2 mM L-cystein (Sigma-Aldrich, St. Louis, MO) originating from the SHIME feed. Anaerobic conditions were obtained by flushing the headspace of the bottles with pure nitrogen gas for 30 cycles. By inserting a sterile syringe through the rubber cap, samples were taken for enterotoxin detection and for B. cereus enumeration by the spread plate method on Tryptone Soya Agar (TSA), except when intestinal bacteria were added. No replicate experiments were performed.

No significant differences were observed between $B$. cereus NVH 1230-88 and B. cereus ATCC 14579, so following experiment was performed with the latter, the type strain $B$. cereus ATCC 14579 . Vegetative cells $(100 \mu \mathrm{L}$ of a $24-\mathrm{h}$ TSB culture at $30^{\circ} \mathrm{C}$ ) were inoculated in $30 \mathrm{~g}$ of lasagne verde (commercially obtained in a local supermarket) in stomacher bags at $30^{\circ} \mathrm{C}$ for $48 \mathrm{~h}$ in triplicate. The enterotoxin production was assessed with the Duopath ${ }^{\circledR}$ kit after filter sterilization $(0.2 \mu \mathrm{m}$ cellulose acetate filter, Whatman) of lasagne samples homogenized and 10 -fold diluted in Physiological Peptone Salt solution $(8.5 \mathrm{~g} / \mathrm{L}$ $\mathrm{NaCl}$ (Sigma-Aldrich), $1 \mathrm{~g} / \mathrm{L}$ peptone (neutralized bacteriological peptone; Oxoid). The total count was determined by plating on TSA and the B. cereus concentration by plating on Mannitol Egg-Yolk Polymyxin-B agar (MYP).

\section{Enterotoxin production by B. cereus under intestinal conditions}

The growth and enterotoxin production of $B$. cereus (strains 1-5 in Table 2) in $200 \mathrm{~mL}$ of intestinal simulation medium at $37^{\circ} \mathrm{C}$ at pH 7.0 (automatic pH controllers Fermac 260; Electrolab, Tewkesbury, UK) under anaerobiosis (30-min flushing of the headspace with nitrogen gas) was investigated in triplicate. The B. cereus inocula consisted of $10 \mathrm{~mL}$ of stationary culture in TSB $\left(24 \mathrm{~h}\right.$ at $\left.30^{\circ} \mathrm{C}\right)$ and $60 \mathrm{~g}$ of lasagne verde (homogenized by stomachering for $3 \mathrm{~min}$ ) as the food source. Every $2 h, B$. cereus was enumerated by plating on TSA and the Duopath $^{\circledR}$ kit tested for enterotoxins $\mathrm{Hbl}$ and Nhe. The intestinal simulation medium contained the following digestive host secretions: bile (bovine dehydrated fresh bile; Difco), pancreatin (from porcine pancreas; Sigma-Aldrich), lipase (porcine lipase; Sigma-Aldrich), and pepsin (from porcine stomach mucosa; Sigma-Aldrich), which were present in the vessels in the final concentrations of, respectively, 1.0, 1.0, 0.2, and $0.2 \mathrm{~g} / \mathrm{L}$. To determine the influence of digestive host secretions on enterotoxin detection and production, these enzymes were omitted during specific experiments. To investigate potential food matrix effects, $57 \mathrm{~mL}$ of sterile TSB 
Table 4. Enterotoxin Stability in Tryptone Soya Broth (TSB), and Gastric and Intestinal Simulation Medium at $37^{\circ} \mathrm{C}$

\begin{tabular}{|c|c|c|c|c|c|}
\hline \multirow[b]{2}{*}{ Medium } & \multirow[b]{2}{*}{ Time $(h)$} & \multicolumn{2}{|c|}{ Haemolysin BL (Hbl) } & \multicolumn{2}{|c|}{ Non-haemolytic enterotoxin (Nhe) } \\
\hline & & $\begin{array}{l}\text { BCET-RPLA } \\
\text { (Oxoid) }\end{array}$ & $\begin{array}{c}\text { Duopath }^{\circledR} \\
\text { (Merck) }\end{array}$ & $\begin{array}{l}\text { Duopath }^{\circledR} \\
\text { (Merck) }^{(\text {Merc }}\end{array}$ & $\begin{array}{c}\text { BDE VIA } \\
(3 M-T e c r a)\end{array}$ \\
\hline \multirow[t]{3}{*}{ TSB (pH 7.2) } & 0.5 & + & + & + & + \\
\hline & 6.0 & + & + & + & + \\
\hline & 24.0 & + & + & + & + \\
\hline \multirow{2}{*}{ Gastric medium ( $\mathrm{pH}$ 5.0) } & 0.5 & + & + & + & + \\
\hline & 2.0 & + & + & + & + \\
\hline \multirow[t]{2}{*}{ Gastric medium (pH 2.0) } & 0.5 & - & - & - & - \\
\hline & 2.0 & - & - & - & - \\
\hline \multirow[t]{3}{*}{ Intestinal medium ( $\mathrm{pH} 6.5$ ) } & 0.5 & + & - & + & - \\
\hline & 1.0 & + & - & - & - \\
\hline & 2.0 & - & - & - & - \\
\hline
\end{tabular}

substituted the $60 \mathrm{~g}$ of lasagne verde as the food source. To enable detection of only newly produced toxins, the enterotoxins in the inoculum's culture supernatant were removed by centrifugation at $5000 \times \mathrm{g}$ for $30 \mathrm{~min}$, followed by resuspension of the cells in $10 \mathrm{~mL}$ of sterile TSB prior to their inoculation in the vessels.

\section{Results}

Performance of the commercial kits for $\mathrm{B}$. cereus enterotoxin detection

The three tested kits were specific for either $\mathrm{Nhe}$ or $\mathrm{Hbl}$ enterotoxin target components, since no cross-reactivity was revealed by the positive controls of the BCET-RPLA (Oxoid) and the BDE $\mathrm{VIA}^{\mathrm{TM}}$ (3M-Tecra) kits, and the negative medium controls (Table 3). Except for the BCET-RPLA kit, which required, respectively, fivefold and twofold dilution of gastric and intestinal medium to prevent false positive results. Supporting evidence for the BDE VIA ${ }^{\mathrm{TM}}$ kit having two target components Nhe-A and Nhe-B (Beecher and Wong, 1994) was found, since its positive Nhe-B control was also detected by the Duopath ${ }^{\circledR}$ kit (Merck). Nevertheless, the detection limit for Hbl-L2 was 10-fold lower with the BCETRPLA kit than with the Duopath ${ }^{\circledR}$ kit, while the Duopath ${ }^{\circledR}$ kit was 10-fold more sensitive for Nhe than the BDE VIA ${ }^{\mathrm{TM}}$ kit (Table 3).

Enterotoxin Nhe and $\mathrm{Hbl}$ detection in the culture supernatant of different $B$. cereus strains with the different kits corresponded well with each other with minor differences (Table 2). The observed differences can be explained by the

Table 5. Production of Enterotoxins by Bacillus cereus During Growth in Gastric and Intestinal Simulation Media at $37^{\circ} \mathrm{C}$ and in Lasagne Verde at $30^{\circ} \mathrm{C}$

\begin{tabular}{|c|c|c|c|c|c|c|}
\hline \multirow[b]{2}{*}{ Growth conditions } & \multirow[b]{2}{*}{ Time $(h)$} & \multirow{2}{*}{$\begin{array}{l}\text { B. cereus }(\log \\
\text { CFU/mL } \pm \text { standard } \\
\text { deviation) }\end{array}$} & \multicolumn{2}{|c|}{$\begin{array}{l}\text { Haemolysin } \\
\text { BL (Hbl) }\end{array}$} & \multicolumn{2}{|c|}{$\begin{array}{l}\text { Non-haemolytic } \\
\text { enterotoxin (Nhe) }\end{array}$} \\
\hline & & & $\begin{array}{l}\text { BCET-RPLA } \\
\quad \text { kit }\end{array}$ & $\begin{array}{l}\text { Duopath } \\
\text { kit }\end{array}$ & $\begin{array}{l}\text { Duopath } \\
\text { kit }\end{array}$ & $\begin{array}{c}\text { BDE } \\
V I A^{\mathrm{TM}} k i t\end{array}$ \\
\hline \multirow{4}{*}{$\begin{array}{l}\text { Gastric medium, micro-aerophilic, } \\
\text { pH 5.0, } 37^{\circ} \mathrm{C}, \text { B. cereus NVH 1230-88 }\end{array}$} & 0 & 5.8 & + & - & + & - \\
\hline & 2 & 6.0 & + & - & + & - \\
\hline & 4 & 7.6 & + & - & + & - \\
\hline & 6 & 7.9 & - & - & + & - \\
\hline \multirow{4}{*}{$\begin{array}{l}\text { Intestinal medium, micro-aerophilic, } \\
\text { pH } 6.5,37^{\circ} \mathrm{C}, \text { B. cereus NVH 1230-88 }\end{array}$} & 0 & 5.8 & + & - & - & - \\
\hline & 2 & 6.0 & + & - & - & - \\
\hline & 4 & 7.8 & - & - & - & - \\
\hline & 6 & 7.9 & - & - & - & - \\
\hline \multirow{4}{*}{$\begin{array}{l}\text { Intestinal medium, anaerobic, } \\
\text { pH } 6.5,37^{\circ} \mathrm{C}, \text { B. cereus NVH } 1230-88\end{array}$} & 0 & 5.8 & + & - & - & - \\
\hline & 2 & 6.1 & - & - & - & - \\
\hline & 4 & 7.5 & - & - & - & - \\
\hline & 6 & 7.8 & - & - & - & - \\
\hline \multirow{4}{*}{$\begin{array}{l}\text { Intestinal medium, anaerobic, } \mathrm{pH} 6.5,37^{\circ} \mathrm{C} \text {, } \\
\text { B. cereus } \mathrm{NVH} 1230-88,6.5 \log \mathrm{CFU} / \mathrm{mL} \\
\text { intestinal bacteria added initially }\end{array}$} & 0 & ND & + & - & - & - \\
\hline & 2 & ND & - & - & - & - \\
\hline & 4 & ND & - & - & - & - \\
\hline & 6 & ND & - & - & - & - \\
\hline \multirow{3}{*}{$\begin{array}{l}\text { Lasagne verde, aerobic, pH } 5.5,30^{\circ} \mathrm{C} \text {, } \\
\text { B. cereus ATCC } 14579,4.8 \log \mathrm{CFU} / \mathrm{mL} \\
\text { bacteria naturally present }\end{array}$} & 0 & $4,5 \pm 0,1$ & ND & - & - & ND \\
\hline & 24 & $7,3 \pm 0,3$ & ND & \pm & \pm & ND \\
\hline & 48 & $7,4 \pm 0,4$ & ND & \pm & \pm & ND \\
\hline
\end{tabular}

+ , positive; - , negative; \pm , both + and - results obtained (one replicate was positive, while two were negative). ND, not determined. 
Table 6. Anaerobic Growth and Enterotoxin Production (Assessed with the Duopath ${ }^{\circledR} \mathrm{Kit}_{\text {) }}$ by Bacillus cereus in Intestinal Simulation Medium with and Without Digestive Secretions and Either Lasagne Verde or Tryptone Soya Broth (TSB) as the Food Source Kept at pH 7.0 and $37^{\circ} \mathrm{C}$

\begin{tabular}{|c|c|c|c|c|c|c|c|c|}
\hline \multirow[b]{2}{*}{ Intestinal medium } & \multirow[b]{2}{*}{ Food source } & \multirow{2}{*}{$\begin{array}{l}\text { B. cereus } \\
\text { inoculum }\end{array}$} & \multirow[b]{2}{*}{ Parameter } & \multicolumn{5}{|c|}{ Time } \\
\hline & & & & $0-1 h$ & $2 h$ & $4 h$ & $6 h$ & $8 h$ \\
\hline \multirow{24}{*}{$\begin{array}{l}\text { Normal composition } \\
\text { (final concentration } \\
\text { of } 1.0 \mathrm{~g} / \mathrm{L} \text { bile, } \\
1.0 \mathrm{~g} / \mathrm{L} \text { pancreatin, } \\
0.2 \mathrm{~g} / \mathrm{L} \text { lipase, } \\
0.2 \mathrm{~g} / \mathrm{L} \text { pepsin) }\end{array}$} & \multirow{18}{*}{$\begin{array}{c}\text { Lasagne } \\
\text { verde }\end{array}$} & \multirow{3}{*}{$\begin{array}{l}\text { B. cereus NVH } \\
1230-88\end{array}$} & $\log \mathrm{CFU} / \mathrm{mL}$ & $5,35 \pm 0,11$ & $5,94 \pm 0,66$ & $6,98 \pm 0,56$ & $7,74 \pm 0,54$ & $8,00 \pm 0,30$ \\
\hline & & & $\mathrm{Hbl}$ & - & - & - & - & - \\
\hline & & & Nhe & - & - & - & - & - \\
\hline & & \multirow{3}{*}{$\begin{array}{l}\text { B. cereus RIVM } \\
\text { 9903295-4 }\end{array}$} & $\log \mathrm{CFU} / \mathrm{mL}$ & $4,83 \pm 0,14$ & $5,18 \pm 0,00$ & $5,90 \pm 0,46$ & $6,40 \pm 0,14$ & $7,24 \pm 0,38$ \\
\hline & & & $\mathrm{Hbl}$ & - & - & - & - & - \\
\hline & & & Nhe & - & - & - & - & - \\
\hline & & \multirow[t]{3}{*}{ B. cereus FF 137} & $\log \mathrm{CFU} / \mathrm{mL}$ & $4,21 \pm 0,20$ & $4,30 \pm 0,03$ & $5,35 \pm 0,41$ & $6,48 \pm 0,40$ & $7,22 \pm 0,29$ \\
\hline & & & $\mathrm{Hbl}$ & - & - & - & - & - \\
\hline & & & Nhe & - & - & - & - & - \\
\hline & & \multirow[t]{3}{*}{ B. cereus FF 73} & $\log \mathrm{CFU} / \mathrm{mL}$ & $5,32 \pm 0,15$ & $5,64 \pm 0,16$ & $7,01 \pm 0,42$ & $7,77 \pm 0,35$ & $8,04 \pm 0,29$ \\
\hline & & & $\mathrm{Hbl}$ & - & - & - & - & - \\
\hline & & & Nhe & - & - & - & - & - \\
\hline & & \multirow{3}{*}{$\begin{array}{l}\text { B. cereus ATCC } \\
14579\end{array}$} & $\log \mathrm{CFU} / \mathrm{mL}$ & $5,53 \pm 0,10$ & $5,71 \pm 0,09$ & $6,75 \pm 0,32$ & $7,44 \pm 0,16$ & $7,73 \pm 0,16$ \\
\hline & & & $\mathrm{Hbl}$ & - & - & - & - & - \\
\hline & & & Nhe & - & - & - & - & - \\
\hline & & \multirow{3}{*}{$\begin{array}{l}\text { B. cereus ATCC } \\
14579 \text { (washed) }\end{array}$} & $\log \mathrm{CFU} / \mathrm{mL}$ & $5,40 \pm 0,16$ & $5,67 \pm 0,04$ & $6,89 \pm 0,48$ & $7,49 \pm 0,33$ & $7,79 \pm 0,29$ \\
\hline & & & $\mathrm{Hbl}$ & - & - & - & - & - \\
\hline & & & Nhe & - & - & - & - & - \\
\hline & \multirow{6}{*}{$\begin{array}{c}\text { Tryptone } \\
\text { Soya } \\
\text { broth } \\
\text { (TSB) }\end{array}$} & \multirow{3}{*}{$\begin{array}{l}\text { B. cereus ATCC } \\
14579\end{array}$} & $\log \mathrm{CFU} / \mathrm{mL}$ & $5,69 \pm 0,07$ & $5,95 \pm 0,07$ & $7,17 \pm 0,38$ & $7,70 \pm 0,18$ & $7,66 \pm 0,09$ \\
\hline & & & $\mathrm{Hbl}$ & - & - & - & - & - \\
\hline & & & Nhe & - & - & - & - & - \\
\hline & & \multirow{3}{*}{$\begin{array}{l}\text { B. cereus ATCC } \\
14579 \text { (washed) }\end{array}$} & $\log \mathrm{CFU} / \mathrm{mL}$ & $5,78 \pm 0,12$ & $5,78 \pm 0,22$ & $6,80 \pm 0,25$ & $7,34 \pm 0,23$ & ND \\
\hline & & & $\mathrm{Hbl}$ & - & - & - & - & - \\
\hline & & & Nhe & - & - & - & - & - \\
\hline \multirow{12}{*}{$\begin{array}{l}\text { No digestive } \\
\text { secretions }\end{array}$} & \multirow{6}{*}{$\begin{array}{c}\text { Tryptone } \\
\text { Soya } \\
\text { broth } \\
\text { (TSB) }\end{array}$} & \multirow{3}{*}{$\begin{array}{l}\text { B. cereus ATCC } \\
14579\end{array}$} & $\log \mathrm{CFU} / \mathrm{mL}$ & $5,62 \pm 0,04$ & $6,57 \pm 0,19$ & $7,74 \pm 0,27$ & $8,03 \pm 0,30$ & $8,04 \pm 0,02$ \\
\hline & & & $\mathrm{Hbl}$ & - & - & + & + & + \\
\hline & & & Nhe & + & + & + & + & + \\
\hline & & \multirow{3}{*}{$\begin{array}{l}\text { B. cereus ATCC } \\
14579 \text { (washed) }\end{array}$} & $\log \mathrm{CFU} / \mathrm{mL}$ & $5,75 \pm 0,34$ & $6,83 \pm 0,04$ & $7,92 \pm 0,08$ & $8,22 \pm 0,32$ & $8,11 \pm 0,11$ \\
\hline & & & $\mathrm{Hbl}$ & - & - & + & + & + \\
\hline & & & Nhe & - & - & + & + & + \\
\hline & \multirow{6}{*}{$\begin{array}{c}\text { Lasagne } \\
\text { verde }\end{array}$} & \multirow{3}{*}{$\begin{array}{l}\text { B. cereus ATCC } \\
14579\end{array}$} & $\log \mathrm{CFU} / \mathrm{mL}$ & $5,70 \pm 0,06$ & $6,19 \pm 0,29$ & $7,82 \pm 0,16$ & $8,35 \pm 0,14$ & $8,65 \pm 0,25$ \\
\hline & & & $\mathrm{Hbl}$ & + & + & + & + & + \\
\hline & & & Nhe & + & + & + & + & + \\
\hline & & \multirow{3}{*}{$\begin{array}{l}\text { B. cereus ATCC } \\
14579 \text { (washed) }\end{array}$} & $\log \mathrm{CFU} / \mathrm{mL}$ & $5,68 \pm 0,11$ & $6,19 \pm 0,20$ & $7,61 \pm 0,20$ & $8,29 \pm 0,27$ & $8,78 \pm 0,18$ \\
\hline & & & $\mathrm{Hbl}$ & - & - & + & + & + \\
\hline & & & Nhe & - & - & + & + & + \\
\hline
\end{tabular}

+ , positive; - , negative.

ND, not determined.

different detection limits of the kits, the varying levels of enterotoxin production among different $B$. cereus strains and the varying enterotoxin production by the same strain under different growth conditions. For example, the supernatant of B. cereus strain LFMFP 381 tested negative for $\mathrm{Hbl}-\mathrm{L} 2$ with the Duopath ${ }^{\circledR}$ kit, but with the more sensitive BCET-RPLA kit a positive result was obtained. Some strains showed variable results for enterotoxin production after different culturing conditions. For example, the psychrotrophic strain LFMFP 710 tested negative for the $\mathrm{Hbl}$ target component after $18 \mathrm{~h}$ incubation in $\mathrm{BHI}$ at $36^{\circ} \mathrm{C}$, but positive results were obtained after $18 \mathrm{~h}$ in $\mathrm{BHI}$ at $30^{\circ} \mathrm{C}$ and $24 \mathrm{~h}$ in $\mathrm{TSB}$ at $30^{\circ} \mathrm{C}$.

\section{Stability of enterotoxins in gastrointestinal simulation media}

The enterotoxin Nhe and $\mathrm{Hbl}$ target components were relatively stable in TSB $\left(>24 \mathrm{~h}\right.$ at $\left.37^{\circ} \mathrm{C}\right)$ and in gastric simulation medium with pH 5.0 ( $>2 \mathrm{~h}$ at $37^{\circ} \mathrm{C}$; Table 4$)$. However, in gastric medium with $\mathrm{pH}$ 2.0, no enterotoxin components were detected, indicating degradation within $30 \mathrm{~min}$ incubation at $37^{\circ} \mathrm{C}$. Also in intestinal medium, the Nhe and $\mathrm{Hbl}$ target components were not stable, resulting in failure of Nhe detection after $0.5-1 \mathrm{~h}$ and after $0.5-2 \mathrm{~h}$ for the $\mathrm{Hbl}$ components, depending on the kit used.

\section{Enterotoxin detection in gastrointestinal simulation media}

Enterotoxins were detected immediately at the start of the experiments by the kits with the lowest detection limits (Table 5). These toxins originated from the inoculum supernatant, i.e., $1 \mathrm{~mL}$ of $B$. cereus culture in the stationary growth phase. After B. cereus NVH 1230-88 had grown in intestinal medium with $\mathrm{pH} 6.5$ for $2-4 \mathrm{~h}$, no enterotoxins were detected anymore, regardless of the presence of oxygen and competing intestinal microbiota. During growth in gastric medium with $\mathrm{pH} 5.0$, Nhe was detected throughout the experiment with the 
Duopath ${ }^{\circledR}$ kit, while $\mathrm{Hbl}$ was detected at $0-4 \mathrm{~h}$ with the BCETRPLA kit.

During growth of B. cereus ATCC 14579 at $30^{\circ} \mathrm{C}$ in the food matrix lasagne verde $(\mathrm{pH}=5.52$, standard deviation of triplicate measurements \pm 0.06 ), enterotoxins $\mathrm{Hbl}$ and Nhe were detected inconsistently after 24 and $48 \mathrm{~h}$, namely, in only one out of three replicates.

\section{Enterotoxin production in intestinal medium and lasagne verde}

B. cereus strains grew anaerobically from approximately 5 $\log \mathrm{CFU} / \mathrm{mL}$ to approximately $8 \log \mathrm{CFU} / \mathrm{mL}$ under intestinal conditions with lasagne verde as food source at $\mathrm{pH} 7.0$ at $37^{\circ} \mathrm{C}$ for $8 \mathrm{~h}$, but no enterotoxins were detected (Table 6). Substitution of lasagne by TSB as the food source gave similar results. To eliminate enzymatic degradation of enterotoxins in the intestinal simulation medium, the digestive host secretions (bile, pepsin, lipase, and pancreatin) were omitted. During these experiments, enterotoxins were detected throughout the experiment, indicating that negative results were obtained by enterotoxin degradation. Experiments were set up with washed inoculums to remove the enterotoxins present in the added inoculum cultures, which enabled detection of only newly produced enterotoxin components. During these experiments, enterotoxins $\mathrm{Hbl}$ and Nhe were detected after $4 \mathrm{~h}$ when the B. cereus population reached $>7$ $\log \mathrm{CFU} / \mathrm{mL}$, but only if no digestive enzymes were added to the intestinal simulation medium.

\section{Discussion}

This study confirmed that diarrheal toxins Nhe and $\mathrm{Hbl}$ are rapidly degraded under intestinal conditions and under gastric conditions at low $\mathrm{pH}$ (Table 5), reinforcing the hypothesis that preformed enterotoxins do not contribute significantly to diarrheal food poisoning (Granum et al., 1993; Turnbull et al., 1979). Moreover, our experiments showed that B. cereus populations of $>7 \log \mathrm{CFU} / \mathrm{mL}$ produced enterotoxins Nhe and $\mathrm{Hbl}$ under intestinal conditions, if host secretions containing digestive enzymes were omitted to prevent enterotoxin degradation (Table 6). Rapid ( $<30 \mathrm{~min}$ ) degradation of enterotoxins by pancreatic enzymes in intestinal simulation medium was also reported in another study (Wijnands et al., 2005). The food matrix may offer protection against heat, acid, or enzymatic inactivation of enterotoxins and increase their stability during gastrointestinal passage, as indicated by the fourfold increased heat resistance of enterotoxin Nhe target components in milk in comparison with BHI (Baker and Griffiths, 1995). During our study, no protective effects of the composite food matrix lasagane verde on the stability and detection of enterotoxins were observed in comparison with TSB. In conclusion, the results of this study reinforce the hypothesis postulated by Wijnands et al. (2005) that enterotoxin production by $B$. cereus should occur in close proximity to the small intestinal epithelium in order to enable the unstable enterotoxins to reach and affect the host cells and cause diarrheal disease.

An important consequence of this hypothesis is that not all ingested B. cereus will contribute to diarrheal food poisoning, since only the ones producing enterotoxins in close proximity to the host epithelial cells are affecting the host. This means that the infective dose does not necessarily correspond with the ingested dose. Our experiments, mimicking the liquid and well-mixed conditions in the intestinal lumen, showed enterotoxin production when the population attained $\geq 7 \log$ $\mathrm{CFU} / \mathrm{mL}$ during the exponential growth phase. Since it was also observed that enterotoxins were rapidly degraded in the intestinal lumen, the question arises at which bacterial concentrations toxin production occurs if B. cereus is adhered to the semi-solid viscous mucus matrix and the intestinal host cells. The growth conditions in the mucus layer near the host cells differ tremendously from those in the intestinal lumen in many aspects, including the dissolved oxygen concentration, the viscosity, available nutrients, the density and diversity of the bacterial community, and the immunological and antimicrobial molecules secreted by the host (Van den Abbeele et al., 2011). The growth and toxin production in the vicinity of the host should be investigated with simulation experiments which mimic this environment to elucidate which numbers of cells produce sufficient enterotoxins to initiate diarrheal disease.

$B$. cereus growth at low $\mathrm{pH}$ often results in delayed, decreased, or even abolished enterotoxin production (Ceuppens et al., 2011). In agreement, enterotoxin production was absent during growth in gastric medium at $\mathrm{pH} 5.0$ and severely impaired in lasagne verde with $\mathrm{pH}$ 5.5.

Three commercial kits for B. cereus enterotoxin detection were evaluated and found suitable to investigate enterotoxin production under gastrointestinal conditions. However, several observations were made that require attention for the correct data interpretation. Firstly, in the case of the BCETRPLA kit (Oxoid), twofold and fivefold dilution of, respectively, intestinal and gastric samples was required to avoid false-positive results, but this was acceptable given its low detection limit. Secondly, the lower limit of $\mathrm{Hbl}$ component detection in a sample is $2 \mathrm{ng} / \mathrm{mL}$ for the BCET-RPLA kit (according to the manufacturers) and $20 \mathrm{ng} / \mathrm{mL}$ for the Duopath ${ }^{\circledR}$ kit (Krause et al., 2010). This corresponds very well with our observations, in contrast to the detection limits for the Nhe components. In the latter case, either the detection limit of the Duopath ${ }^{\circledR}$ kit is lower than the suggested $6 \mathrm{ng} / \mathrm{mL}$ (Krause et al., 2010) or the detection limit of the BDE VIA ${ }^{\mathrm{TM}} \mathrm{kit}$ is higher than the limit of $1 \mathrm{ng} / \mathrm{mL}$ claimed by the manufacturer. Thirdly, false negative results were sometimes obtained for psychrotrophic strains due to their decreased growth rate at high $\left(>30^{\circ} \mathrm{C}\right)$ temperatures, which was also observed during earlier studies (Moravek et al., 2006). This problem originates from the kits' instructions to test the cell-free culture supernatant of the strains after incubation at a fixed time and temperature, and can be overcome by performing the test when a certain cultures density is reached instead of a certain incubation time, which may be insufficient for certain slowgrowing strains. Fourthly, not all enterotoxin polymorphisms are detected by the kits, for example the NheB component produced by B. cereus NVH 391/98 was not recognized by the Duopath ${ }^{\circledR}$ kit (Krause et al., 2010). It remains to be investigated whether these toxin variants have biological activity and thus whether they should be detected by the commercial kits. Moreover, Nhe and / or Hbl production was reported for other bacilli such as B. circulans, B. licheniformis, B. pumilus, B. polymyxa, B. carotarum, and B. lentus, using the BDE VIA ${ }^{\mathrm{TM}}$ and BCET-RPLA kits (Beattie and Williams, 1999; Griffiths, 1990). However, enterotoxin gene sequences were exclusively retrieved from B. cereus group strain genomes using NCBI megablast (Ceuppens et al., 2011). Therefore, it remains to be 
clarified whether other bacilli can produce similar enterotoxins or whether some cross-reactivity of the kits' antibodies exists. Fifthly, it must be noted that the immunological detection of enterotoxin target components not necessarily imply the presence of biologically active enterotoxins (Buchanan and Schultz, 1994). For example, thermal inactivation prevented Nhe detection with the BDE VIA ${ }^{\mathrm{TM}}$ kit, but not that of Hbl-L2 with the BCET-RPLA.

\section{Acknowledgments}

This work was supported by the Special Research Funds of Ghent University as a part of the project Growth Kinetics, Gene Expression and Toxin Production by Bacillus cereus in the Small Intestine (B/09036/02 fund IV1, October 31, 2008 to October 31, 2012) and by the Research Foundation Flanders (Fonds Westenschappelijk Onderzoek - Vlanderen - FWO) postdoctoral mandate of Dr. Andreja Rajkovic.

\section{Disclosure Statement}

No competing financial interests exist.

\section{References}

Baker JM, Griffiths MW. Evidence for increased thermostability of Bacillus cereus enterotoxin in milk. J Food Prot 1995;58:443-445.

Beattie SH, Williams AG. Detection of toxigenic strains of $\mathrm{Ba}-$ cillus cereus and other Bacillus spp. with an improved cytotoxicity assay. Lett Appl Microbiol 1999;28:221-225.

Beecher DJ, Wong ACL. Identification and analysis of the antigens detected by 2 commercial Bacillus cereus diarrheal enterotoxin immunoassay kits. Appl Environ Microbiol 1994;60:4614-4616.

Buchanan RL, Schultz FJ. Comparison of the Tecra Via kit, Oxoid BCET-RPLA kit and CHO cell culture assay for the detection of Bacillus cereus diarrheal enterotoxin. Lett Appl Microbiol 1994;19:353-356.

Ceuppens S, Boon N, Rajkovic A, Heyndrickx M, Van de Wiele T, Uyttendaele M. Quantification methods for Bacillus cereus vegetative cells and spores in the gastrointestinal environment. J Microbiol Methods 2010;83:202-210.

Ceuppens S, Rajkovic A, Heyndrickx M, Tsilia V, De Wiele TV, Boon N, Uyttendaele M. Regulation of toxin production by Bacillus cereus and its food safety implications. Crit Rev Microbiol 2011;37:188-213.

Delbrassinne L, Andjelkovic M, Rajkovic A, Bottledoorn N, Mahillon J, Van Loco J. Follow-up of the Bacillus cereus emetic toxin production in penne pasta under household conditions using liquid chromatography coupled with mass spectrometry. Food Microbiol 2011;28:1105-1109.

Gilois N, Ramarao N, Bouillaut L, Perchat S, Aymerich S, Nielsen-Leroux C, Lereclus D. Growth-related variations in the Bacillus cereus secretome. Proteomics 2007;7:1719-1728.

Granum PE, Brynestad S, Osullivan K, Nissen K. Enterotoxin from Bacillus cereus: Production and biochemical characterization. Neth Milk Dairy J 1993;47:63-70.

Griffiths MW. Toxin production by psychrotrophic Bacillus spp. present in milk. J Food Prot 1990;53:790-792.
Krause N, Moravek M, Dietrich R, Wehrle E, Slaghuis J, Martlbauer E. Performance characteristics of the Duopath ${ }^{\circledR}$ Cereus Enterotoxins assay for rapid detection of enterotoxinogenic Bacillus cereus strains. Int J Food Microbiol 2010;144:322-326.

Molly K, Van de Woestyne M, Verstraete W. Development of a 5-step multi-chamber reactor as a simulation of the human intestinal microbial ecosystem. Appl Microbiol Biotechnol 1993;39:254-258.

Moravek M, Dietrich R, Buerk C, BroussolleV, Guinebretiere $\mathrm{MH}$, Granum PE, Nguyen-The C, Martlbauer E. Determination of the toxic potential of Bacillus cereus isolates by quantitative enterotoxin analyses. FEMS Microbiol Lett 2006;257: 293-298.

Oomen AG, Rompelberg CJ, Bruil MA, Dobbe CJ, Pereboom DP, Sips AJ. Development of an in vitro digestion model for estimating the bioaccessibility of soil contaminants. Arch Environ Contam Toxicol 2003;44:281-287.

Possemiers S, Verthe K, Uyttendaele S, Verstraete W. PCRDGGE-based quantification of stability of the microbial community in a simulator of the human intestinal microbial ecosystem. FEMS Microbiol Ecol 2004;49:495-507.

Rajkovic A, Uyttendaele M, Vermeulen A, Andjelkovic M, FitzJames I, in 't Veld P, Denon Q, Vérhe R, Debevere J. Heat resistance of Bacillus cereus emetic toxin, cereulide. Lett Appl Microbiol 2008;46:536-541.

Shinagawa K, Ueno Y, Hu D, Ueda S, Sugii S. Mouse lethal activity of a HEp-2 vacuolation factor, cereulide, produced by Bacillus cereus isolated from vomiting-type food poisoning. J Vet Med Sci 1996;58:1027-1029.

Turnbull PC, Kramer JM, Jorgensen K, Gilbert RJ, Melling J. Properties and production characteristics of vomiting, diarrheal, and necrotizing toxins of Bacillus cereus. Am J Clin Nutr 1979;32:219-228.

Van den Abbeele P, Van de Wiele T, Verstraete W, Possemiers S. The host selects mucosal and luminal associations of coevolved gut microorganisms: A novel concept. FEMS Microbiol Rev 2011;35:681-704.

Wehrle E, Moravek M, Dietrich R, Burk C, Didier A, Martlbauer E. Comparison of multiplex PCR, enzyme immunoassay and cell culture methods for the detection of enterotoxinogenic Bacillus cereus. J Microbiol Methods 2009;78:265-270.

Wijnands L, Dufrenne J, van Leusden F. Bacillus cereus: Characteristics, behaviour in the gastro-intestinal tract, and interaction with Caco-2 cells. RIVM report 250912003/2005 2005.

Address correspondence to: Andreja Rajkovic, Ph.D.

Faculty of Bioscience Engineering Laboratory of Food Microbiology and Food Preservation (LFMFP)

Ghent University

Coupure Links 653

B-9000 Ghent, Belgium

E-mail: andreja.rajkovic@ugent.be 